\title{
Lagerindicine, a New Pyrrole Alkaloid Isolated from the Flowers of Lagerstroemia indica Linnaeus
}

\author{
Yi Chen $^{2,3}$ - Song-Wei Li ${ }^{1}$. Fang-Zhou Yin ${ }^{1} \cdot$ Min Yang ${ }^{1} \cdot$ Xia-Juan Huan ${ }^{1}$ Ze-Hong Miao ${ }^{1}$ Xiao-Ming Wang ${ }^{2,3}$. \\ Yue-Wei Guo ${ }^{1,4}$
}

Received: 13 August 2020 / Accepted: 12 October 2020 / Published online: 20 October 2020

(c) The Author(s) 2020

\begin{abstract}
A phytochemical investigation of the EtOH extract of the flowers of Lagerstroemia indica L. led to the isolation and characterization of a new pyrrole alkaloid, named lagerindicine (1), along with four known compounds (2-5). Their structures were elucidated by the detailed spectroscopic analysis and comparison with literature data, whereas the structure, in particularly, the absolute configuration (AC) of $\mathbf{1}$, was firmly determined by total synthesis. All the isolates were evaluated for their cytotoxic effects against human colon cancer cell (HCT-116), and compound $\mathbf{3}$ exhibited weak cytotoxicity with IC $_{50}$ value of $28.4 \mu \mathrm{M}$.
\end{abstract}

\section{Graphic Abstract}

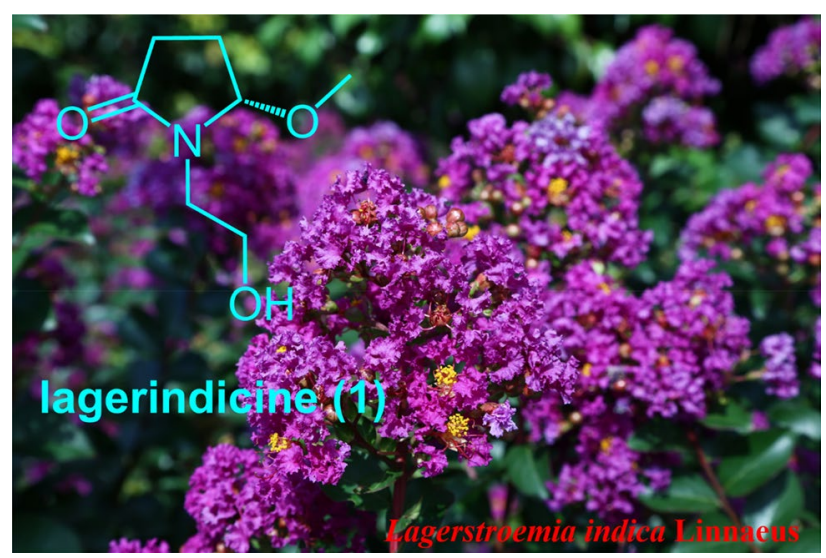

Keywords Lagerstroemia indica Linnaeus · Pyrrole alkaloid · Total synthesis · Stereochemistry · Cytotoxicity

Electronic supplementary material The online version of this article (https://doi.org/10.1007/s13659-020-00273-x) contains supplementary material, which is available to authorized users.

Xiao-Ming Wang

wxm1964@163.com

Yue-Wei Guo

ywguo@simm.ac.cn

1 State Key Laboratory of Drug Research, Shanghai Institute of Materia Medica, Chinese Academy of Sciences, 555 Zu Chong Zhi Road, Zhangjiang Hi-Tech Park, Shanghai 201203, China
2 Hunan Academy of Forestry, 658 South Shao shan Road, Changsha 410004, Hunan, China

3 Changsha Engineering Technology Research Center of Woody Flower, 658 South shao shan Road, Changsha 410004, Hunan, China

4 College of Materials Science and Engineering, Central South University of Forestry and Technology, 498 South Shao shan Road, Changsha 410004, Hunan, China 


\section{Introduction}

Terrestrial plants of Lythracea is a large family, widely used in architecture, landscaping, food and drug applications. The plants of genus Lagerstroemia comprise more than 15 species, which are either small trees or shrubs with colourful flowers distributed in warm temperate regions of China [1]. Earlier chemical investigation of the different species of Lythracea can trace back to decades, and a lot of structurally diverse and complex compounds, such as alkaloids, sesqui-, triterpenoids, steroids and flavonoids [2] were reported. Especially, alkaloids have attracted much attention of natural product chemists and pharmacologists due to their extensive biological activities, ranging from antifungal activities to cytotoxicity. The earlier phytochemical studies on the plants of the Lagerstroemia indica initiated in 1962. Ferris et al. had reported a series of phenylquinolizidine alkaloids from the aerial of title species [3-8]. Recently, several new biphenylquinolizidine alkaloids were also isolated from the aerial parts of $L$. indica by Bae et al. $[9,10]$. It is interesting to note that the chemical constituents of the flowers of $L$. indica are not reported till now.

In our continuous efforts towards the searching for novel bioactive secondary metabolites from marine and terrestrial sources [11-14], we have recently collected the fresh flowers of $L$. indica $\mathrm{L}$. from Hunan Province, China, and carried out a chemical investigation on the EtOH extract of the flowers. As a result, a new pyrrole alkaloid, namely lagerindicine (1), and four known compounds (2-5) were isolated and characterized. Herein, we reported the isolation, structural elucidation, especially total synthesis of $\mathbf{1}$, and in vitro biological evaluation of these isolates (Fig. 1).

\section{Results and Discussion}

The $n$ - $\mathrm{BuOH}$ and EtOAc soluble portion of the EtOH extract was repeatedly column chromatographed over silica gel, Sephadex LH-20, and RP-HPLC to yield pure compounds $\mathbf{1}, \mathbf{2}$, and 3-5, respectively. The structures of the known compounds $\mathbf{2}-\mathbf{5}$ were rapidly identified as pterolactam [15], betulinic acid [16], oleanolic acid [17] and 24-methylenecycloartanol [18], respectively, by the comparison of their spectral data and optical rotations with those reported in the literature.

Compound 1, named lagerindicine, was isolated as a colorless oil. Its molecular formula was determined to be $\mathrm{C}_{7} \mathrm{H}_{13} \mathrm{O}_{3} \mathrm{~N}$ by the ${ }^{13} \mathrm{C}$ NMR data and HR-ESIMS positive ion at $\mathrm{m} / z 182.0782[\mathrm{M}+\mathrm{Na}]^{+}$(calcd. for $\mathrm{C}_{7} \mathrm{H}_{13} \mathrm{NO}_{3} \mathrm{Na}$, 182.0788), indicating two degrees of unsaturation. Consistent with this data, analysis of the ${ }^{13} \mathrm{C}$ NMR and the HSQC
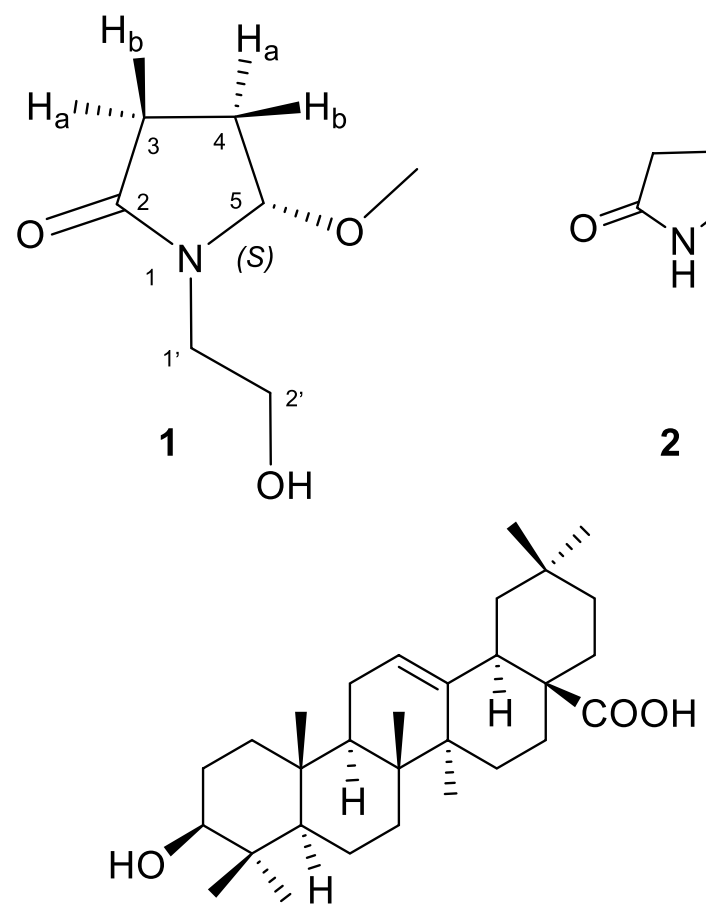

4

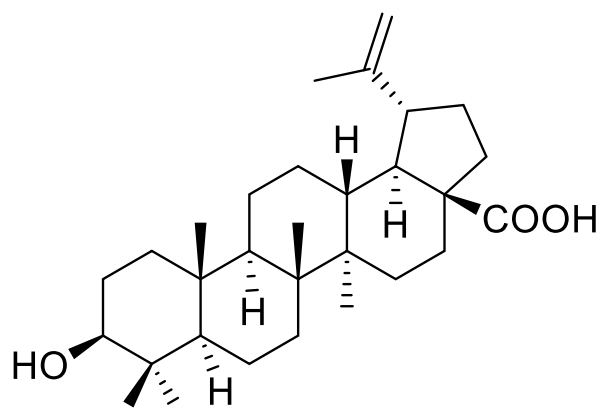

3<smiles>C=C(CC[C@@H](C)[C@H]1CC[C@]2(C)[C@H]3CC[C@H]4C(C)(C)[C@@H](O)CC[C@]45C[C@@]35CC[C@]12C)C(C)C</smiles>

Fig. 1 Structures of compounds $\mathbf{1}-\mathbf{5}$ 
spectra revealed the presence of 7 carbon signals, comprising one $\mathrm{sp}^{3}$ methyl carbon (oxygenated at $\delta_{\mathrm{C}} 53.7$ ), four $\mathrm{sp}^{3}$ methylene carbons (one oxygenated at $\delta_{\mathrm{C}} 60.5$ ), one $\mathrm{sp}^{3}$ methine carbon (oxygenated at $\delta_{\mathrm{C}} 92.8$ ), and one carbonyl carbon resonating at $\delta_{\mathrm{C}} 178.2$ (Table 1). The ${ }^{1} \mathrm{H}$ NMR data showed resonance of one methoxyl singlet at $\delta_{\mathrm{H}} 3.31(3 \mathrm{H}$, $\mathrm{s},-\mathrm{OMe})$. The four protons resonating at $\delta_{\mathrm{H}} 3.67(2 \mathrm{H}$, each t, $J=5.8 \mathrm{~Hz}, \mathrm{H}-2 \mathrm{a}^{\prime}$ and $\left.\mathrm{H}-2 \mathrm{~b}^{\prime}\right), \delta_{\mathrm{H}} 3.55(1 \mathrm{H}, \mathrm{dt}, J=14.0$, $\left.5.8 \mathrm{~Hz}, \mathrm{H}-1 \mathrm{a}^{\prime}\right)$, and $\delta_{\mathrm{H}} 3.27\left(1 \mathrm{H}, \mathrm{dt}, J=14.0,5.8 \mathrm{~Hz}, \mathrm{H}-1 \mathrm{~b}^{\prime}\right)$, along with the corresponding carbons at $\delta_{\mathrm{C}} 60.5\left(\mathrm{C}-2^{\prime}\right)$ and $44.3\left(\mathrm{C}-1^{\prime}\right)$, indicated the presence of hydroxyethyl group. Furthermore, the four protons resonating at $\delta_{\mathrm{H}} 2.50(1 \mathrm{H}$, $\mathrm{dt}, J=17.3,8.6 \mathrm{~Hz}, \mathrm{H}-3 \mathrm{a}), \delta_{\mathrm{H}} 2.32(1 \mathrm{H}, \mathrm{ddd}, J=17.3,9.9$, $2.8 \mathrm{~Hz}, \mathrm{H}-3 \mathrm{~b}), \delta_{\mathrm{H}} 2.21(1 \mathrm{H}, \mathrm{dddd}, J=13.8,9.9,8.6,6.1 \mathrm{~Hz}$, $\mathrm{H}-4 \mathrm{a})$, and $\delta_{\mathrm{H}} 2.02(1 \mathrm{H}$, dddd, $J=13.8,8.6,2.8,1.2 \mathrm{~Hz}$, $\mathrm{H}-4 \mathrm{~b})$, together with the coupled oxymethine proton at $\delta_{\mathrm{H}}$ $5.08(1 \mathrm{H}, \mathrm{dd}, J=1.2,6.1 \mathrm{~Hz}, \mathrm{H}-5)$, suggested the direct connection from $\mathrm{C}-3$ to $\mathrm{C}-5$ through $\mathrm{C}-4$. The above observations were further supported by the ${ }^{1} \mathrm{H}-{ }^{1} \mathrm{H}$ COSY correlations (Fig. 2). In HMBC spectrum, the correlation between -OMe to C-5 $\left(\delta_{\mathrm{C}} 92.7\right)$ suggested the methoxyl locating at C-5. All the above NMR data closely resembled those of the co-occurring compound 2, pterolactam [(S)-5-methoxypyrrolidin-2-one], a known alkaloid previously isolated from the aerial parts of Chrysanthemum coronarium L. (family Compositae) [15]. In fact, 1 differs from 2 only ascribing to the substituent at N-1. Due to the replacement of the hydrogen atom of $\mathrm{N}-1$ in 2 by the hydroxyethyl group in $\mathbf{1}$, the ${ }^{13} \mathrm{C}$ NMR chemical shifts of the vicinal carbons at C-2 and C-5 of $\mathbf{1}$, respect to those of $\mathbf{2}$, were upfield and downfield shifted (Table 1), respectively, according to the 44 mass units differences between them. The hydroxyethyl linked at N-1 in $\mathbf{1}$ was further confirmed by the observed key HMBC correlations from $\mathrm{H}_{2}-1$ ' to $\mathrm{C}-2$ and $\mathrm{C}-5$ (Fig. 2). Thus, the planar structure of compound $\mathbf{1}$ was unambiguously determined as

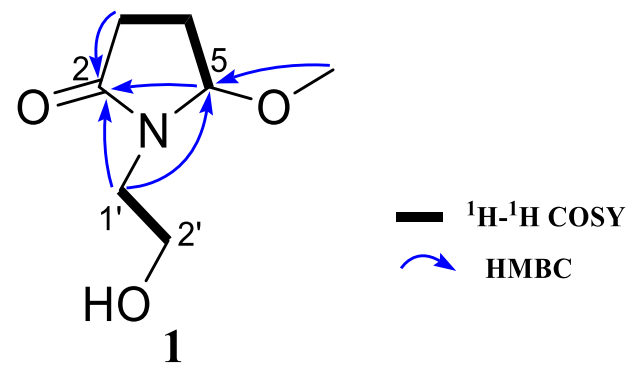

Fig. $2{ }^{1} \mathrm{H}-{ }^{1} \mathrm{H}$ COSY and the key HMBC correlations of compound 1

depicted in Fig. 2. Lagerindicine is $N$-hydroxyethyl derivative of 2.

Since there is only one chiral center (C-5) in compound $\mathbf{1}$, the final step to complete the full structure of $\mathbf{1}$ is to determine its absolute configuration. Since the AC of cooccurring related compound $\mathbf{2}$ is $5 S$ [15], it is obvious that $\mathbf{1}$ should share the same $S$ absolute configuration at C-5 based on the biogenetic consideration.

This assignment was supported by observing the same optical rotation signs of both compounds $\mathbf{1}$ and $\mathbf{2}\{\mathbf{1}$ : $\left.[\alpha]_{\mathrm{D}}^{20}+13(c 0.05 \mathrm{MeOH}) ; \mathbf{2}:[\alpha]_{\mathrm{D}}^{20}+12(c 0.2 \mathrm{MeOH})\right\}$. However, considering the different substitution pattern at $\mathrm{N}-1$, which may cause unexpected influence on the optical properties of $\mathbf{1}$ and $\mathbf{2}$, we decided to synthesize $\mathbf{1}$ so as to confirm the deduced absolute stereochemistry of $\mathbf{1}$. As shown in Scheme 1, a total synthesis of both (+)- and (-)-enantiomers of 1 was carried out. Thus, the key intermediate 2-pyrrol-1-ylethan-1-ol (7) was prepared starting from the commercially available 2,5-dimethoxytetrahydrofuran (6) [19]. The photooxidation of pyrrole 7 in the presence of Rose Bengal (RB, sensitizer) and methanol as polar solvent under irradiation with a $250 \mathrm{~W}$ long arc mercury lamp afforded ( \pm )-5-methoxylactam (8) [20], which, in turn,
Table $1{ }^{1} \mathrm{H}$ and ${ }^{13} \mathrm{C}$ NMR data of compound $\mathbf{1}^{\mathrm{a}}$ and $\mathbf{2}^{\mathrm{b}}$

\begin{tabular}{|c|c|c|c|c|}
\hline \multirow[t]{2}{*}{ No. } & \multicolumn{2}{|l|}{1} & \multicolumn{2}{|l|}{2} \\
\hline & $\delta_{\mathrm{H}}($ mult, $J$ in $\mathrm{Hz})$ & $\delta_{\mathrm{C}}$, type & $\delta_{\mathrm{H}}($ mult, $J$ in Hz) & $\delta_{\mathrm{C}}$, type \\
\hline 2 & & $178.2, \mathrm{C}$ & & $181.4, \mathrm{C}$ \\
\hline $3 \mathrm{a}$ & $2.50(\mathrm{dt}, 17.3,8.6)$ & $29.8, \mathrm{CH}_{2}$ & $2.40(\mathrm{dt}, 16.0,8.4)$ & $29.4, \mathrm{CH}_{2}$ \\
\hline $3 b$ & $2.32(\mathrm{ddd}, 17.3,9.9,2.8)$ & & $2.14(\mathrm{ddd}, 16.0,6.4,2.0)$ & \\
\hline $4 a$ & 2.21 (dddd, 13.8, 9.9, 8.6, 6.1) & $24.8, \mathrm{CH}_{2}$ & 2.26 (dddd, $13.2,6.4,8.4,6.4)$ & $28.8, \mathrm{CH}_{2}$ \\
\hline $4 b$ & 2.02 (dddd, 13.8, 8.6, 2.8, 1.2) & & 1.97 (dddd, 13.2, 8.4, 2.0, 1.2) & \\
\hline 5 & $5.08(\mathrm{dd}, 1.2,6.1)$ & $92.8, \mathrm{CH}$ & $4.85(\mathrm{dd}, 1.2,6.4)$ & $88.7, \mathrm{CH}$ \\
\hline $1 \mathrm{a}^{\prime}$ & $3.55(\mathrm{dt}, 14.0,5.8)$ & $44.3, \mathrm{CH}_{2}$ & & \\
\hline $1 b^{\prime}$ & $3.27(\mathrm{dt}, 14.0,5.8)$ & & & \\
\hline $2^{\prime}$ & $3.67(\mathrm{t}, 5.8)$ & $60.5, \mathrm{CH}_{2}$ & & \\
\hline$-\mathrm{OCH}_{3}$ & $3.31(\mathrm{~s})$ & $53.7, \mathrm{CH}_{3}$ & $3.26(\mathrm{~s})$ & $54.8, \mathrm{CH}_{3}$ \\
\hline
\end{tabular}

${ }^{\mathrm{a}} \mathrm{At} 400 \mathrm{MHz}$ for ${ }^{1} \mathrm{H}$ and $100 \mathrm{MHz}$ for ${ }^{13} \mathrm{C} \mathrm{NMR}$ experiments in $\mathrm{CD}_{3} \mathrm{OD} . \delta(\mathrm{ppm})$ were referenced to $\mathrm{MeOH}\left(\delta_{\mathrm{H}} 3.31, \delta_{\mathrm{C}} 49.0\right)$, assignments made by DEPT, ${ }^{1} \mathrm{H}-{ }^{1} \mathrm{H}$ COSY, HSQC, and HMBC experiments

${ }^{\mathrm{b}} \mathrm{At} 400 \mathrm{MHz}$ for ${ }^{1} \mathrm{H}$ and $100 \mathrm{MHz}$ for ${ }^{13} \mathrm{C}$ NMR experiments in $\mathrm{CD}_{3} \mathrm{OD}$, [15] 


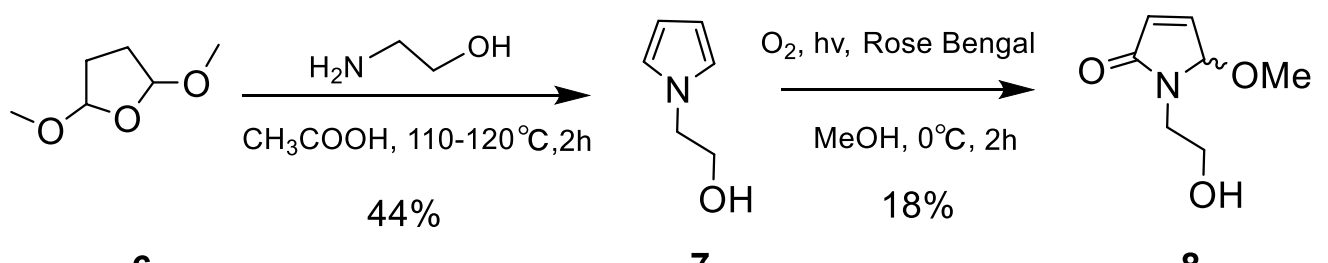

6

7

8

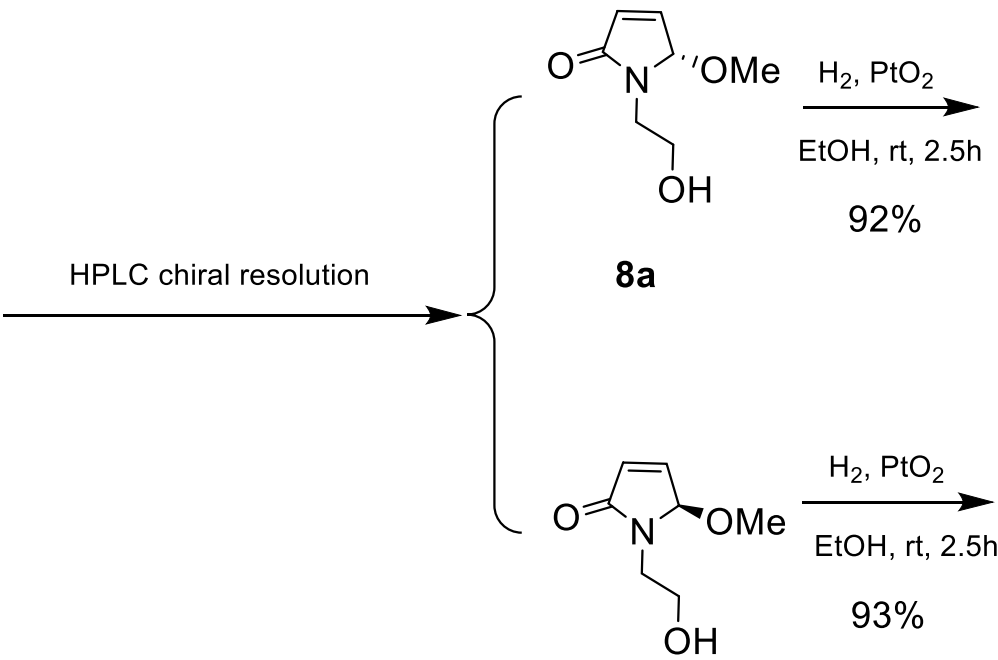

$8 b$<smiles>CO[C@H]1CCC(=O)N1CCO</smiles>

$(+)-1$<smiles>CO[C@H]1CCC(=O)N1CCO</smiles>

$(-)-1$

Scheme 1 Total synthetic route of (+)-1 and (-)-1
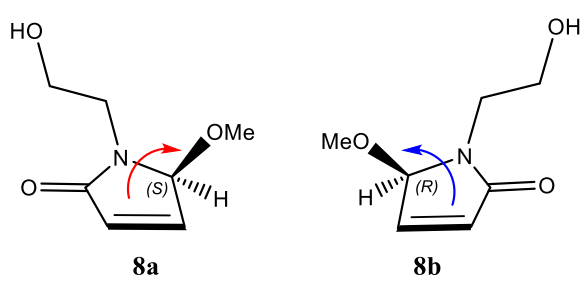

$8 \mathbf{b}$

$$
\begin{aligned}
& \mathrm{n}-\pi^{*}(235-250 \mathrm{~nm}) \\
& \pi-\pi^{*}(200-215 \mathrm{~nm})
\end{aligned}
$$

$\Delta \varepsilon<0$

$\Delta \varepsilon>0$

$\Delta \varepsilon>0$

$\Delta \varepsilon<0$

Fig. 3 Correlation of the Cotton effects with absolute configuration

was further separated by the chiral-phase HPLC to generate the expected (+)-5-methoxylactam $\left\{\mathbf{8 a},[\alpha]_{\mathrm{D}}^{20}+131(c 0.1\right.$ $\mathrm{MeOH})\}$ and (-)-5-methoxylactam $\left\{\mathbf{8 b},[\alpha]_{\mathrm{D}}^{20}-121(c 0.1\right.$ $\mathrm{MeOH})\}$, respectively. Furthermore, as the presence of a $\alpha, \beta$-unsaturated lactone chromophore in structures $8 \mathbf{a}$ and $\mathbf{8 b}$, the absolute configuration of this pair of optically pure enantiomers could be further determined to be $5 S$ and $5 R$, respectively, by the observed opposite Cotton effects due to the $\mathrm{n}-\pi^{*}$ and $\pi-\pi^{*}$ transitions (Fig. 3) [21], in combination

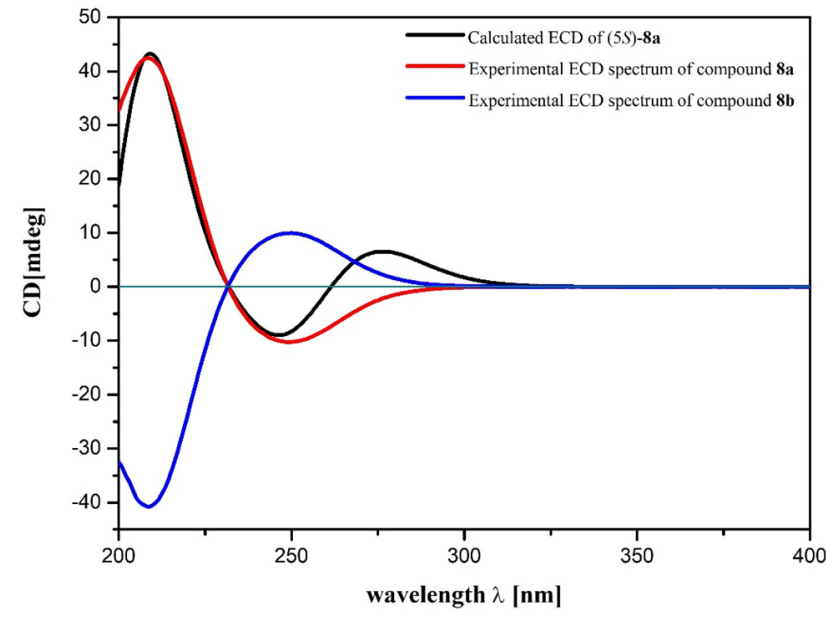

Fig. 4 The TDDFT-ECD calculation results of $\mathbf{8 a}$ and $\mathbf{8 b}$

with the results of TDDFT-ECD calculation (Fig. 4), respectively. Having confirmed the $\mathrm{AC}$ at $\mathrm{C}-5$, the subsequent reduction of the olefin of $\mathbf{8 a}$ and $\mathbf{8 b}$ with $\mathrm{PtO}_{2}$ in $\mathrm{EtOH}$ yielded the target molecule (+)-1 and its enantiomer (-)-1, respectively. Finally, overall comparison of the physical and 
chemical data of synthetic (+)-1 with those of natural product 1 confirmed the $5 S$ absolute stereochemistry of natural 1 .

Considering that the promising biological activities of pyrrole alkaloids [22], we have performed in vitro biological evaluation of all the isolated compounds on human colon cancer cell line (HCT-116). The cytotoxic effects were evaluated against HCT-116 with TAK-243 (MLN7243) as the positive control. As shown in Table 2, only compound 3 showed weak cytotoxicity with the $\mathrm{IC}_{50}$ value of $28.4 \mu \mathrm{M}$. Furthermore, other pharmaceutical screens, such as antimicrobial, anti-inflammatory, and insecticidal assays are undergoing.

In conclusion, this is the first phytochemical investigation on the flowers of $L$. indica L. Interestingly, the previously reported metabolites from the different parts of the title plant, such as phenyl quinolizidine alkaloids, flavonoids, and flavone glycosides, etc. were not found in the present work. Moreover, it is noteworthy that pyrrole alkaloids $\mathbf{1}$ and $\mathbf{2}$ were isolated from the plants belonging to family Lythracea for the first time. The real origin of $\mathbf{1}$ is a matter worth to discuss since having used $\mathrm{EtOH}$ in the extraction process. To rule out the possibility that $\mathbf{1}$ may be an artificial product, we have tried to treat compound $\mathbf{2}$ by dissolving it in $\mathrm{EtOH}$ and stirred overnight at room temperature, but failed to detect the presence of $\mathbf{1}$.

Further study should be conducted to extend the screening range to other bioassays such as anti-inflammatory, antimicrobe etc. on alkaloids $\mathbf{1}$ and $\mathbf{2}$ since the supply issue of these intriguing compounds has been solved by synthetic method.

\section{Experimental}

\subsection{General Experimental Procedures}

Optical rotations were measured on a Perkin-Elmer 241MC polarimeter (PerkinElmer, Fremont, CA, USA). ECD spectra

Table 2 The inhibitory effect of the isolated compounds on the proliferation of HCT-116 were recorded on a Jasco J-810 spectropolarimeter (JASCO, Japan) at ambient temperature using chromatographic grade $\mathrm{CH}_{3} \mathrm{OH}$ and acetonitrile as solvent. IR spectra were recorded on a Nicolet Magna FT-IR 750 spectrometer (Thermo Scientific, Waltham, MA, USA); peaks are reported in $\mathrm{cm}^{-1}$. The NMR spectra were measured at $300 \mathrm{~K}$ on a Bruker DRX$400\left(400 \mathrm{MHz}\right.$ for ${ }^{1} \mathrm{H}$ and $100 \mathrm{MHz}$ for ${ }^{13} \mathrm{C}$ ) spectrometer (Bruker Biospin AG, Fällanden, Germany), Chemical shifts ( $\delta)$ are reported in parts per million (ppm) in $\mathrm{CD}_{3} \mathrm{OD}$ and coupling constants $(J)$ in $\mathrm{Hz}$, with the residual $\mathrm{CH}_{3} \mathrm{OH}$ ( $\delta_{\mathrm{H}}=3.31$ and $\delta_{\mathrm{C}}=49.0$ ) as internal standard. LR-ESIMS and HR-ESIMS were carried out on a Bruker Daltonics Esquire 3000 plus instrument (Bruker Daltonics K. K., Kanagawa, Japan) and a Waters Q-TOF Ultima mass spectrometer (Waters, MA, USA), respectively. The semi-preparative HPLC was performed on an Agilent 1260 series liquid chromatography equipped with a DAD G1315D detector at 210 and $254 \mathrm{~nm}$, and a semi-preparative ODS-HG-5 column [5 $\mu \mathrm{m}, 250 \times 9.4 \mathrm{~mm}$ ] was also employed. Commercial silica gel (Qingdao Haiyang Chemical Co., Ltd., Qingdao, China, 200-300 mesh, 300-400 mesh) was used for column chromatography, Sephadex LH-20 gel (Amersham Biosciences) was used for column chromatography and precoated silica gel plates (Yan Tai Zi Fu Chemical Group Co., Yantai, China, G60 F-254) were used for analytical TLC. All solvents used for extraction and isolation were of analytical grade.

\subsection{Plant Material}

The flowers of $L$. indica L. were collected from the experimental forest farm of Hunan Academy of Forestry, Hunan province, China, in July 2019. The plant was identified by Dr Xiao-Ming Wang (Hunan Academy of Forestry, Hunan, China). A voucher specimen (No. 19-HN-1) was deposited at the Shanghai Institute of Materia Medica, Chinese Academy of Sciences.

\subsection{Extraction and Isolation}

The fresh flowers $(10 \mathrm{~kg})$ were picked off on the morning, and then dried at room temperature. The dried flowers were crushed and extracted exhaustively three times with $95 \%$ EtOH $(3 \times 5 \mathrm{~L})$, each time for $24 \mathrm{~h}$. After evaporation of the solvent under vacuum, the concentrate was suspended in $\mathrm{H}_{2} \mathrm{O}(2 \mathrm{~L})$, acidified to $\mathrm{pH} 4 \sim 5$ with $\mathrm{H}_{2} \mathrm{SO}_{4}$, extracted three times with EtOAc $(3 \times 2 \mathrm{~L})$. The EtOAc extract $(59.9 \mathrm{~g})$ was obtained after removing the solvents under vacuum. The aqueous layer was then basified with $\mathrm{Na}_{2} \mathrm{CO}_{3}$ to $\mathrm{pH}$ 9 10 and extracted three times with $\mathrm{CHCl}_{3}(3 \times 2 \mathrm{~L})$, after filtration, the organic solvents were removed under vacuum to give the $\mathrm{CHCl}_{3}$ extract $(0.5 \mathrm{~g})$. The aqueous layer was further extracted three times with $n$ - $\mathrm{BuOH}(3 \times 2$ 
L). After filtration, the organic solvents were removed under vacuum to give the $n$ - $\mathrm{BuOH}$ extract $(5.0 \mathrm{~g})$. The $n$-BuOH extract was successively separated by silica column chromatography $(\mathrm{CC})$ (column: $30 \times 6 \mathrm{~cm}$, eluting with petroleum ether: Acetone $=100: 0 \rightarrow 0: 100)$, Sephadex LH-20 CC (column: $150 \times 4 \mathrm{~cm}$, eluting with dichloromethane: methanol $=1: 1$ ), and reversed-phase HPLC $\left(\mathrm{CH}_{3} \mathrm{CN}: \mathrm{H}_{2} \mathrm{O}=5: 95\right)$ to afford compound 1 (3.6 mg, $t_{\mathrm{R}}=16.0 \mathrm{~min}$ ) and compound $2\left(4.1 \mathrm{mg}, t_{\mathrm{R}}=14.6 \mathrm{~min}\right)$. The EtOAc extract was repeatedly separated via silica CC (column: $30 \times 6 \mathrm{~cm}$, eluting with petroleum ether: diethyl ether $=100: 0 \rightarrow 0: 100$ ), and Sephadex LH-20 CC (column: $150 \times 4 \mathrm{~cm}$, eluting with petroleum ether: dichloromethane: methanol $=2: 1: 1)$ to obtain compound $3(4.8 \mathrm{mg})$, compound 4 (38.0 $\mathrm{mg}$ ) and compound 5 (10.3 mg).

\subsubsection{Lagerindicine (1)}

Colorless oil; $[\alpha]_{\mathrm{D}}^{20}+13(c 0.05 \mathrm{MeOH})$; UV $(\mathrm{MeOH})$ $\lambda_{\max }(\log \varepsilon) 210(3.10) \mathrm{nm}, \lambda_{\max }(\log \varepsilon) 270(2.20) \mathrm{nm}$; IR: $v=3418,2932,1682,1456,1373,1259,1175$, 1076, $800 \mathrm{~cm}^{-1}$; ${ }^{1} \mathrm{H}$ and ${ }^{13} \mathrm{C}$ NMR data see Table 1; HRESIMS $m / z 182.0782[\mathrm{M}+\mathrm{Na}]^{+}$(calcd. for $\mathrm{C}_{7} \mathrm{H}_{13} \mathrm{NO}_{3} \mathrm{Na}$, 182.0788).

\subsubsection{Pterolactam (2)}

White amorphous powder $(\mathrm{MeOH}) ;[\alpha]_{\mathrm{D}}^{20}+12(c \quad 0.2$ $\mathrm{MeOH})$; Lit [15]: $[\alpha]_{\mathrm{D}}^{20}+10(c 0.1, \mathrm{MeOH}) .{ }^{1} \mathrm{H}$ NMR and ${ }^{13} \mathrm{C}$ NMR data see Table 1.

\subsection{Synthesis Procedures}

\subsubsection{2-Pyrrol-1-ylethan-1-ol (7)}

Ethanolamine $(6.6 \mathrm{~mL}, 0.1 \mathrm{mmol})$ was added to glacial acetic acid $(12 \mathrm{~mL})$ at $0{ }^{\circ} \mathrm{C}$, and kept the temperature at $15-25^{\circ} \mathrm{C}$. Then, 2,5- dimethoxytetrahydrofuran $(6)(3.4 \mathrm{~mL}$, $0.02 \mathrm{mmol}$ ) was added and the reaction was stirred at $110-120^{\circ} \mathrm{C}$. After $2 \mathrm{~h}$ at that temperature, the residual liquid in the reaction vessel was cooled to $\mathrm{rt}$ and water was added. The usual work-up (DCM, brine, saturated aqueous $\mathrm{Na}_{2} \mathrm{CO}_{3}$ ) afforded a residue that was dissolved in $\mathrm{MeOH}$ (6.7 mL). $\mathrm{NaOH}$ (20 wt \%, $3.3 \mathrm{~mL}$ ) was added, and the solution was stirred at $\mathrm{rt}$ for $1 \mathrm{~h}$, then poured into brine, and extracted with DCM. The solvent was removed under reduced pressure to afford $7(1.2 \mathrm{~g}, 44 \%)$ as a yellow oil. The spectroscopic data of 7 are as follows: ${ }^{1} \mathrm{H}$ NMR $(400 \mathrm{MHz}$, $\left.\mathrm{CDCl}_{3}\right) \delta_{\mathrm{H}} 6.70(\mathrm{t}, 2 \mathrm{H}), 6.18(\mathrm{t}, 2 \mathrm{H}), 4.00(\mathrm{t}, 2 \mathrm{H}), 3.81(\mathrm{t}$, 2H) $\mathrm{ppm}$.

\subsubsection{1-(2-Hydroxyethyl)-5-methoxy-1H-pyrrol-2(5H)-one} (8)

A solution of the compound $7(1.8 \mathrm{mmol})$ in methanol $(50 \mathrm{~mL})$ containing a catalytic amount of sensitizer Rose Bengal (RB) was placed in a flask, and oxygen was gently bubbled through it. The solution was cooled to $0{ }^{\circ} \mathrm{C}$ and irradiated with a $250 \mathrm{~W}$ long arc mercury lamp for $2 \mathrm{~h}$. The photooxidations gave complex mixtures of oxygenated products, and compound 8 (49.9 mg, 18\%) were purified by flash column chromatography using silica gel (petroleum ether/acetone $=5: 1 \rightarrow 1: 1 \mathrm{v} / \mathrm{v}) .8 \mathbf{8 a}\{20.1 \mathrm{mg}$, $\left.[\alpha]_{\mathrm{D}}^{20}+131(c 0.1 \mathrm{MeOH}), t_{\mathrm{R}}=7.5 \mathrm{~min}\right\}$ and $\mathbf{8 b}\{20.3 \mathrm{mg}$, $\left.[\alpha]_{\mathrm{D}}^{20}-121(c 0.1 \mathrm{MeOH}), t_{\mathrm{R}}=10.0 \mathrm{~min}\right\}$ were obtained through the chiral-phase HPLC resolution of $\mathbf{8}$ (CHIRAPAK IC, Lot No. IC00CE-QH040) (20\% isopropanol, flow rate: $2 \mathrm{~mL} / \mathrm{min})$. The spectroscopic data of $\mathbf{8}$ are as follows: ${ }^{1} \mathrm{H} \mathrm{NMR}\left(400 \mathrm{MHz}, \mathrm{CDCl}_{3}\right) \delta_{\mathrm{H}} 6.90(\mathrm{dd}, 1 \mathrm{H}, J=1.6$, $6.1 \mathrm{~Hz}), 6.23(\mathrm{dd}, 1 \mathrm{H}, J=0.7,6.1 \mathrm{~Hz}), 5.47$ (br s, $1 \mathrm{H})$, $3.73(\mathrm{~m}, 2 \mathrm{H}), 3.56(\mathrm{~m}, 1 \mathrm{H}), 3.41(\mathrm{~m}, 1 \mathrm{H}), 3.12(\mathrm{~s}, 3 \mathrm{H})$ ppm; ${ }^{13} \mathrm{C}$ NMR $\left(100 \mathrm{MHz}, \mathrm{CDCl}_{3}\right) \delta_{\mathrm{C}} 170.7,144.1,130.3$, 89.3, 61.3, 51.0, $43.1 \mathrm{ppm}$

\subsection{3 ( \pm )-Lagerindicine (1)}

Compound 8a (9.6 mg, $0.067 \mathrm{mmol})$ and $\mathbf{8 b}(11.5 \mathrm{mg}$, $0.071 \mathrm{mmol}$ ) in $5 \mathrm{~mL}$ of $\mathrm{EtOH}$ were reduced with $\mathrm{H}_{2}$ at room temperature, using the catalytic amount of $\mathrm{PtO}_{2}$ $(2.0 \mathrm{mg})$ as catalyst, respectively. At the end of $2.5 \mathrm{~h}$, the mixtures were filtered. Upon removed of the EtOH, compounds $(+)-1\left\{8.9 \mathrm{mg},[\alpha]_{\mathrm{D}}^{20}+6.8(c 0.1 \mathrm{MeOH}), 92 \%\right\}$ and (-)-1 $\left\{10.9 \mathrm{mg},[\alpha]_{\mathrm{D}}^{20}-12.7(c 0.1 \mathrm{MeOH}), 93 \%\right)$ were obtained, respectively. The NMR spectra of (+)-1 and (-)1 see Figure S19-22.

\subsection{Cytotoxicity Assays}

The cytotoxicity of the isolated compounds was evaluated against the HCT-116 by using the sulforhodamine B (SRB) method, according to the protocols described in previous literature [23]. The cytotoxicity of the compounds was expressed as the half-maximal inhibition $\left(\mathrm{IC}_{50}, \mu \mathrm{M}\right)$. TAK243 (MLN7243) was used as a positive control.

Acknowledgements This research work was financially supported by the National Natural Science Foundation of China (NSFC) (Nos. 81991521, 41676073), the National Key Research and Development Program of China (No. 2018YFC0310903), the Drug Innovation Major Project (No. 2018ZX09711-001-001-009), and the SKLDR/ SIMM Project (No. SIMM1903ZZ-04). Changsha Engineering Technology Research Center of Woody flower (kq1907081). 


\section{Compliance with Ethical Standards}

Conflict of interest The authors declare no conflict of interest.

Open Access This article is licensed under a Creative Commons Attribution 4.0 International License, which permits use, sharing, adaptation, distribution and reproduction in any medium or format, as long as you give appropriate credit to the original author(s) and the source, provide a link to the Creative Commons licence, and indicate if changes were made. The images or other third party material in this article are included in the article's Creative Commons licence, unless indicated otherwise in a credit line to the material. If material is not included in the article's Creative Commons licence and your intended use is not permitted by statutory regulation or exceeds the permitted use, you will need to obtain permission directly from the copyright holder. To view a copy of this licence, visit http://creativecommons.org/licenses/by/4.0/.

\section{References}

1. H.N. Qin, S. Graham, Flora of China 13, 277-281 (2007)

2. R.M. Labib, N.A. Ayoub, A.B. Singab, M.M. Al-Azizi, A. Sleem, Phytopharmacology 4, 373-389 (2013)

3. J.P. Ferris, J. Org. Chem. 27, 2985-2990 (1962)

4. J.P. Ferris, J. Org. Chem. 28, 817-822 (1963)

5. J.P. Ferris, C.B. Boyce, R.C. Briner, J. Am. Chem. Soc. 93, 2942 $2953(1971)$

6. J.P. Ferris, C.B. Boyce, R.C. Briner, J. Am. Chem. Soc. 93, 2953$2957(1971)$

7. J.P. Ferris, C.B. Boyce, R.C. Briner, J. Am. Chem. Soc. 93, 2958 2962 (1971)
8. J.P. Ferris, C.B. Boyce, R.C. Briner, U. Weiss, I.H. Qureshi, N.E. Sharpless, J. Am. Chem. Soc. 93, 2963-2968 (1971)

9. H.J. Kim, I.S. Lee, U.J. Youn, Q.C. Chen, T.M. Ngoc, D.T. Ha, H. Liu, B.S. Min, J.Y. Lee, R.S. Seong, K.H. Bae, J. Nat. Prod. 72, 749-752 (2009)

10. I.S. Lee, U.J. Youn, H.J. Kim, B.S. Min, J.S. Kim, K.H. Bae, Planta Med. 77, 2037-2041 (2011)

11. Y.S. Cai, T. Kurtán, Z.H. Miao, A. Mándi, I. Komáromi, H.L. Liu, J. Ding, Y.W. Guo, J. Org. Chem. 76, 1821-1828 (2011)

12. X.L. Chen, H.L. Liu, J. Li, G.R. Xin, Y.W. Guo, Org. Lett. 13, 5032-5035 (2011)

13. Z.F. Zhou, W. Zhang, T. Kurtan, A. Mandi, A. Bényei, J. Li, O. Taglialatela-Scafati, Y.W. Guo, Tetrahedron 70, 6444-6449 (2014)

14. J.R. Wang, S.T. Kurtán, A. Mándi, Y.W. Guo, Eur. J. Org. Chem. 2012, 5471-5482 (2012)

15. M.C. Song, H.J. Yang, T.S. Jeong, K.T. Kim, N.I. Beak, Arch. Pharm. Res. 31, 573-578 (2008)

16. S. Khaliq, F. Volk, A.W. Frahm, Planta Med. 73, 77-83 (2007)

17. A. Ikuta, H. Itokawa, J. Nat. Prod. 52, 623-628 (1989)

18. K. Yoshida, Y. Hirose, Y. Imai, T. Kondo, Agric. Biol. Chem. 53, 1901-1912 (1989)

19. N. Trombach, O. Hild, D. Schlettwein, D. Wohrle, J. Mater. Chem. 12, 879-885 (2002)

20. M.N. Alberti, G.C. Vougioukalakis, M. Orfanopoulos, J. Org. Chem. 74, 7274-7282 (2009)

21. J.K. Gawronski, A.V. Oeveren, H.V.D. Deen, C.W. Leung, B.L. Feringa, J. Org. Chem. 61, 1513-1515 (1996)

22. A.E. Dascalu, A. Ghinet, E. Lipka, C. Furman, B. Rigo, A. Fayeulle, M. Billamboz, Fitoterapia 143, 104581 (2020)

23. S. Li, F. Ye, Z. Zhu, H. Huang, S. Mao, Y. Guo, Acta Pharm. Sin. B 8, 944-955 (2018) 